\title{
Species- and sex-specific variations in binding of ochratoxin A by renal proteins in vitro
}

\author{
Alexandra H. Heussner, Evelyn O’Brien, and Daniel R. Dietrich
}

With 3 figures and 4 tables

Address for correspondence: Dr. Daniel R. Dietrich, Environmental Toxicology, University of Konstanz, Jacob-Burckhardtstr. 25, PO Box X918, D-78457 Konstanz, Germany; Tel.: ++49-7531-883581, Fax: ++49-7531-883170, e-mail: daniel.dietrich@uni-konstanz.de

Key words: Ochratoxin A; renal protein binding; renal toxicity; organic anion transporter.

\section{Summary}

The mycotoxin ochratoxin A (OTA) is a potent renal carcinogen in rodents and induces renal fibrosis in pigs. Furthermore, OTA has been associated with the development of renal tumors and nephropathies in humans. Large species- and sex-differences are observed in sensitivity toward OTA-mediated toxicity and carcinogenicity, yet neither the mechanism(s) resulting in OTA toxicity nor the reasons for the observed species- and sex-specificities are known. This paper investigated variations in OTA handling viz binding to renal proteins which could possibly explain the observed differences in OTA susceptibility in vivo and in vitro. The results obtained via a modification of a standard receptor-binding assay demonstrated the presence of at least one homogeneous binding component in renal cortical homogenates from pig, mouse, rat and humans. This component was shown to bind OTA in a specific and saturable manner. A range of compounds selected for their affinity for steroid receptors and/or for various known organic anion transporters were employed in a competition assay to answer the question whether this homogenous OTA binding component represents a steroid-like receptor component or one of the known organic anion transporters of the kidney. Although many of the compounds were able to compete with OTA for protein-binding, the competition patterns displayed a distinct species specificity and did not correspond to the competition patterns associated with presently known organic anion transporters of the kidney in the mouse, rat or human. The data thus suggests the presence of a new organic anion transporter or more likely, a cytosolic binding component of unknown function with high affinity and capacity for OTA binding in humans, rats, mice and possibly pigs.

\section{Introduction}

The mycotoxin ochratoxin A (OTA), a secondary metabolite of ubiquitous Aspergillus and Penicillium species, is a known contaminant of human foodstuffs (SPeIJERS and VAN EGMOND 1993; StUder-RoHr et al. 1995; WolfF et al. 2000). In a number of in vivo models OTA has been observed to induce renal tumors (mice and rats) and nephropathies (pigs) (ElLING 1983). Tumor-incidence was markedly species- and sex-specific with males being at least 10-times more susceptible than females DiETRICH and RASONYI 1995; RASONYI et al. 1999; BENDELE et al. 1985). Moreover, OTA has also been associated with the high incidences of human urinary tract tumors and nephropathies in endemic areas of the Balkans (TATU et al. 1998).

Similarly, stark species- and sex-specific variations in OTA-mediated toxicity have also been observed in renal epithelial cells in vitro (O'BriEN et al. 2001; DIETRICH et al. 2001). Whether these species- and sex-specific differences are governed by specific renal handling of OTA is the subject of the present investigation. Indeed, the comparison of serum/plasma half-lives of OTA in a number of species - 35.5 days in humans (STUDER-RoHR et al. 2000), 21-35 days in monkeys (HAGELBERG et al. 1989), 40 hours in mice (FUKUI et al. 1987, HAGELBERG et al. 1989), 55-120 hours in rats and 72-120 hours in pigs (GAltier et al. 1981, Hagelberg et al. 1989; MORTENSEN et al. 1983) - supports the hypothesis that OTA is excreted, reabsorbed and bound in the renal cortex in a species-specific manner. 
The study presented here, therefore investigated interspecies and inter-sex variations in the binding capacities and/or affinities of OTA to renal cortical proteins by using a classical competitive protein-binding assay with tritiated OTA and protein homogenates of renal cortical tissue of both sexes, from relevant model species (rat, mouse, pig) and from humans. The compounds chosen as competitors for the detection of a potential renal OTA binding protein included ochratoxin B (OTB), (a natural analog of OTA, which differs from OTA only by the substitution of a hydrogen for the chlorine on the isocoumarin moiety), fumonisin $\mathrm{B}_{1}\left(\mathrm{FB}_{1}\right.$, a secondary metabolite of Fusarium moniliformes), cephaloridine, nalidixic acid, furosemide, ethacrynic acid, indomethacin, valproate, sulfobromophthalein (BSP), dehydroiso-androsterone-3-sulfate (DHEAS), digoxin, several bile acids, p-aminohippurate $(\mathrm{PAH})$, caprylic acid, probenecid, piroxicam, $\alpha$-ketoglutarate, steroids, coumarin and phenylalanine. While OTB, coumarin, phenylalanine and the steroids were specifically chosen for their immediate structural analogies to OTA, OTB was also of interest due to its significantly lower toxicity in vivo (Doster et al. 1972; PеCKHAM et al. 1971). All compounds other than $\mathrm{FB}_{1}$ were chosen either because they have been shown to be substrates of the renal organic anion transporters suggested to be responsible for OTA transport (table 1) in the respective animals (ENDOU, 1998; Roch-RAMEL, 1998; SAUVANT et al. 1998) or because of their known potency to inhibit OTA uptake into proximal tubular cells (GROVES et al. 1998; GROVES et al. 1999; WELBORN et al. 1998).

Thus, the focus of this study was to examine OTA binding to renal proteins and to investigate sex- and species-specific differences in binding patterns, which could explain the in vivo and in vitro observed toxicity differences. The data obtained should provide a basis for future research as well as for the comparison with previously published data.

\section{Materials and methods}

Materials: Highly purified ochratoxin A and B (> 98\% purity, benzene free) were kindly provided by Dr. M. E. Stack, U.S. FDA, Washington, D.C. Unless otherwise stated, all other chemicals were purchased from Sigma, Taufkirchen, Germany.

Table 1. Transporter overview.

\begin{tabular}{lllr}
\hline species transporter & $\begin{array}{l}\text { transport } \\
\text { substrates }\end{array}$ & transport inhibitors & references
\end{tabular}

\begin{tabular}{|c|c|c|c|c|}
\hline rat & $\mathrm{OAT}^{\mathrm{a}}$ & PAH & $\begin{array}{l}\text { CEP, NAA, FUR, ETA, IND, PRO, VPA, } \alpha \mathrm{KG} \text {, } \\
\text { methotrexate }\end{array}$ & SEKINE et al. 1997 \\
\hline rat & OAT $1^{\mathrm{a}}$ & PAH & $\alpha K G, P R O$, methotrexate, no effect with TCA & UwAI et al. 1998 \\
\hline rat & OAT $1^{\mathrm{a}}$ & TCA & & UWAI et al. 1998 \\
\hline rat & OAT1 ${ }^{\mathrm{a}, \mathrm{d}}$ & OTA & PIR, PRO, PAH & TsuDA et al. 1999 \\
\hline rat & OAT $1^{\mathrm{a}}$ & PAH & $\mathrm{PRO}, \alpha \mathrm{KG}$ & ENDOU 1998 \\
\hline rat & OAT $1^{\mathrm{a}}$ & PAH & & SwEET et al. 1997 \\
\hline rat & OAT2a & PAH & BSP, CA & SEKINE et al. 1998 \\
\hline rat & $\mathrm{OAT}^{\mathrm{a}}$ & $\alpha \mathrm{KG}$, salicylate & SEKINE et al. 1998 & \\
\hline rat & OAT3 $^{\mathrm{a}}$ & OTA, PAH & $\begin{array}{l}\text { several bile acids, BSP, PIR, FUR, } \\
\text { no effect with IND, DIG }\end{array}$ & KUSUHARA et al. 1999 \\
\hline rat & OAT3 $^{\mathrm{a}}$ & estrone sulfate & & KUSUHARA et al. 1999 \\
\hline rat & OAT-K $1^{\mathrm{e}}$ & methotrexate & BSP, TCA, PRO, PAH, FUR, VPA & SAITO et al. 1996 \\
\hline rat & OAT-K1 $1^{\mathrm{e}}$ & no uptake of PAH & & SAITO et al. 1996 \\
\hline rat & OAT-K $1^{\mathrm{e}}$ & TCA & & SAITO et al. 1996 \\
\hline rat & OAT-K1 ${ }^{\mathrm{e}}$ & methotrexate & IND & MASUDA et al. 1997 \\
\hline rat & OAT-K $1^{\mathrm{e}}$ & no uptake of IND & & MASUDA et al. 1997 \\
\hline rat & $\mathrm{OAT}-\mathrm{K} 2^{\mathrm{c}}$ & TCA & $\begin{array}{l}\text { BSP, IND, TCA, deoxycholate and } \\
\text { other bile acids, PRO, } \\
\text { PAH, FUR, DIG, methotrexate, } \\
\text { TEST, no effect with } \beta E \text {, VPA }\end{array}$ & MASUDA et al. 1999 \\
\hline mouse & mOAT1 ${ }^{\mathrm{a}}$ & PAH & $\mathrm{PRO}, \alpha \mathrm{KG}, \mathrm{IND}$ & KuZE et al. 1999 \\
\hline human & hOAT1 $^{\mathrm{a}}$ & PAH & FUR, IND, PRO, $\alpha \mathrm{KG}$ & HOSOYAMADA et al. 1999 \\
\hline
\end{tabular}

Expression models: ${ }^{\mathrm{a}}$ Xenopus laevis oocytes, ${ }^{\mathrm{b}} \mathrm{COS}-7$ cells, ${ }^{\mathrm{c}}$ MDCK cells, ${ }^{\mathrm{d}}$ mouse $\mathrm{S} 3$ cells, ${ }^{\mathrm{e}}$ LLC-PK1 cells Abbreviations: see table 2. 
$\left[{ }^{3} \mathrm{H}\right]$-ochratoxin A with a specific activity of 6.66 $\mathrm{Bq} / \mathrm{mmol}$ was purchased from Moravek Biochemicals, U.S.A., and was diluted with absolute ethanol. Stock solutions and dilutions of potential binding competitors were prepared with the appropriate vehicle as listed in table 2 .

Animals and tissues: Female and male Fischer rats $\left(\mathrm{CDF}^{\circledR}(\mathrm{F} 344) / \mathrm{Crl} \mathrm{BR}\right)(150-200 \mathrm{~g})$ and $\mathrm{C} 57 \mathrm{Bl} / 6 \mathrm{~J} \times \mathrm{C} 3 \mathrm{H}$, F1-mice were purchased from Charles River, Germany and Harlan, Germany, respectively, and maintained by veterinarians and specifically skilled animal personnel in the animal research facility (TFA) of the University of Konstanz.

Whole kidneys from freshly-killed improved German hybrid pigs of both sexes were obtained from a local slaughter-house.

Human tissue samples: Human renal biopsy material (male and female patients) was obtained from a local hospital (Klinikum Konstanz) in collaboration with the Department of Urology, Prof. Dr. Hochberg and Prof. Dr. Thiel, subsequent to patient information and receipt of the signed patient's consent form. Tissue samples as well as patient data were handled in accordance to the stipulations put forth by the ethics committee of the University of Konstanz and in fulfillment of German law and the Declaration of Helsinki (1964) pertaining to personal data protection and handling of human biopsy material.

Preparation of protein samples: Human and animal renal cortex samples were placed in ice-cold homogenization buffer $(10 \mathrm{mM}$ Tris, $1.5 \mathrm{mM}$ EDTA, $20 \mathrm{mM}$ sodium molybdate, $10 \%(\mathrm{v} / \mathrm{v})$ glycerol, $0.1 \%$ (v/v) monothioglycerol, $0.4 \mathrm{mM}$ PMSF, pH 7.4) and minced with a scissors. Samples were homogenized using 10 strokes of a motordriven teflon pestle in a glass tube. The crude homogenates were then centrifuged at $4{ }^{\circ} \mathrm{C}$ for $20 \mathrm{~min}$ at $10,000 \times \mathrm{g}$. Supernatants were collected and protein content was determined using the standard Bradford procedure. All samples were diluted with homogenization buffer to $5 \mathrm{mg}$ protein $/ \mathrm{ml}$, aliquoted and stored at $-80{ }^{\circ} \mathrm{C}$ until use.
Protein binding assay: Prior to characterization of the OTA-binding proteins, initial experiments were carried out to optimize incubation conditions. Briefly, increasing concentrations $(0.1-5 \mathrm{mg} / \mathrm{sample})$ of cortex proteins were incubated with various concentrations $(1 \mathrm{nM}-200 \mathrm{nM})$ of $\left[{ }^{3} \mathrm{H}\right]$-OTA at $4{ }^{\circ} \mathrm{C}$, room temperature $\left(22 \pm 1{ }^{\circ} \mathrm{C}\right)$ or $37{ }^{\circ} \mathrm{C}$. Specific binding was determined following different incubation time-points by liquid scintillation spectrometry. The incubation conditions at which maximum specific binding was achieved $\left(0.5 \mathrm{mg}\right.$ protein, $100 \mathrm{nM}\left[{ }^{3} \mathrm{H}\right]-O T A, 1$ hour, room temperature) was subsequently considered optimal and was used routinely for all following experiments. In order to determine the equilibrium dissociation constant $\left(\mathrm{K}_{\mathrm{D}}\right)$ and the maximum number of binding sites $\left(\mathrm{b}_{\max }\right)$, a modification of the standard receptor binding procedure was employed. Briefly, approximately $0.5 \mathrm{mg}$ cortex protein in a final volume of $280 \mu \mathrm{l}$ were incubated with $\left[{ }^{3} \mathrm{H}\right]-$ OTA/OTA $(1: 1)$ at final concentrations ranging between $50-800 \mathrm{nM}$ in the presence or absence of 1,000-fold excess OTA at room temperature for 1 hour in order to determine non-specific binding (NB) and total binding (TB), respectively. Unbound $\left[{ }^{3} \mathrm{H}\right]-\mathrm{OTA}$ was removed from the solution by the addition of $300 \mu \mathrm{l}$ dextran $(0.375 \%)$-coated charcoal $(3.75 \%)$ suspension in $0.01 \mathrm{M}$ Tris- $\mathrm{HCl}, \mathrm{pH} 7.4$, to each sample tube. The tubes were vigorously mixed and then centrifuged at $12,000 \mathrm{rpm}$ for 10 seconds at room temperature using an Eppendorf microfuge. A $300 \mu \mathrm{l}$ aliquot of the resulting supernatant was mixed with $3 \mathrm{ml}$ scintillation fluid (Ready Safe, Beckman, Fullerton, U.S.A.) and quantified by liquid scintillation spectrometry using a LS 6500 scintillation counter (Beckman, Fullerton, U.S.A.). Specific binding (SB) was calculated as the difference between $\mathrm{TB}$ and NB. $\mathrm{K}_{\mathrm{D}}$ and $\mathrm{b}_{\max }$ were calculated by Scatchard analysis and non-linear regression analysis using GraphPad Prism software.

For competition binding studies approximately $0.5 \mathrm{mg}$ cortex protein in a final volume of $280 \mu \mathrm{l}$ were incubated with $\left[{ }^{3} \mathrm{H}\right]$-OTA/OTA $(1: 1)$ at a final concentration of 100 $\mathrm{nM}$ in the presence or absence of 1,000-fold excess OTA.

Table 2. Stock solutions and concentration ranges tested.

\begin{tabular}{|c|c|c|c|}
\hline abbreviation (substance) & range $[\mu \mathrm{M}]$ & abbreviation (substance) & range $[\mu \mathrm{M}]$ \\
\hline OTA (ochratoxin A) ${ }^{1}$ & $0.001-1000$ & CHOL (cholesterol) ${ }^{1}$ & $1-1000$ \\
\hline OTB (ochratoxin B) ${ }^{1}$ & $0.001-250$ & TCA (sodium taurocholate) ${ }^{1}$ & $1-1000$ \\
\hline BSP (sodium sulfobromophthalein) ${ }^{2}$ & $0.001-1000$ & DHCA (sodium dehydrocholate) ${ }^{2}$ & $0.001-1000$ \\
\hline DHEAS (Dehydroisoandrosterone-3-sulfate) ${ }^{2}$ & $1-5000$ & PAH (sodium p-aminohippurate) ${ }^{1}$ & $1-1000$ \\
\hline IND (indomethacin) ${ }^{1}$ & $10-1000$ & $\mathrm{COU}(\text { coumarin })^{1}$ & $1-1000$ \\
\hline FUR (furosemide) ${ }^{3}$ & $0.01-1000$ & TEST (testosterone) ${ }^{1}$ & $1-1000$ \\
\hline NAA (sodium nalidixate) ${ }^{5}$ & $10-2500$ & PHE (DL-phenylalanine) ${ }^{1}$ & $1-1000$ \\
\hline ETA (ethacrynic acid) $)^{5}$ & $0.1-5000$ & $\beta E(\beta \text {-estradiol })^{1}$ & $1-250$ \\
\hline PRO (probenecid) ${ }^{1}$ & $1-5000$ & VPA (sodium valproate) ${ }^{1}$ & $1-1000$ \\
\hline PIR (piroxicam) ${ }^{4}$ & $10-1000$ & $\operatorname{AL}\left((- \text { aldosterone })^{1}\right.$ & $1-1000$ \\
\hline CPA (sodium caprylate) $)^{2}$ & $1-5000$ & GSH (reduced glutathione) $)^{2}$ & $0.001-1000$ \\
\hline $\mathrm{CA}(\text { sodium cholate })^{1}$ & $0.001-1000$ & PYR (sodium pyruvate) ${ }^{2}$ & $1-1000$ \\
\hline CDCA (sodium chenodeoxycholate) ${ }^{1}$ & $0.001-1000$ & $\alpha \mathrm{KG}(\text { sodium (-ketoglutarate) })^{2}$ & $1-1000$ \\
\hline DIG (digoxin) ${ }^{1}$ & $10-250$ & CEP $(\text { cephaloridine })^{2}$ & $1-1000$ \\
\hline $\mathrm{FB}_{1}$ (fumonisin $\left.\mathrm{B}_{1}\right)^{2}$ & $1-1000$ & $\mathrm{FA}(\text { folic acid })^{6}$ & $1-1000$ \\
\hline
\end{tabular}

Vehicles: ${ }^{1}$ ethanol, ${ }^{2} \mathrm{H}_{2} \mathrm{O},{ }^{3}$ methanol, ${ }^{4}$ acetonitrile, ${ }^{5}$ chloroform, ${ }^{6} 0.1 \mathrm{M}$ bicarbonate 
Table 3. $\left[{ }^{3} \mathrm{H}\right] \mathrm{OTA}$ protein binding characteristics.

\begin{tabular}{|c|c|c|c|c|c|c|c|c|}
\hline species & $\begin{array}{l}\mathrm{K}_{\mathrm{D}}^{\mathrm{a})} \\
{[\mu \mathrm{M}]}\end{array}$ & $\begin{array}{l}\mathrm{b}_{\max }^{\mathrm{a})} \\
{[\mathrm{pmol} / \mathrm{mg}} \\
\text { protein] }\end{array}$ & $\begin{array}{l}\mathrm{K}_{\mathrm{D}}^{\mathrm{b})} \\
{[\mu \mathrm{M}]}\end{array}$ & $\begin{array}{l}\mathrm{b}_{\max }^{\mathrm{b})} \\
{[\mathrm{pmol} / \mathrm{mg}} \\
\text { protein] }\end{array}$ & $\mathrm{n}$ & $\begin{array}{l}100 \% \mathrm{SB}^{\mathrm{c})} \\
{[\mathrm{pmol} / \mathrm{mg}} \\
\text { protein] }\end{array}$ & $\begin{array}{l}\mathrm{SB} \text { of } \mathrm{TB}^{\mathrm{c})} \\
{[\%]}\end{array}$ & $\mathrm{n}$ \\
\hline human (m) & $1.77 \pm 0.01$ & $296.7 \pm 34.7$ & $2.22 \pm 0.93$ & $352.5 \pm 147.4$ & 3 & $21.4 \pm 4.5$ & $20.5 \pm 4.1$ & 6 \\
\hline human (f) & $3.83 \pm 0.74$ & $1,589.5 \pm 280.7$ & $2.96 \pm 0.67$ & $1,271.8 \pm 241.5$ & 3 & $23.1 \pm 4.7$ & $22.0 \pm 4.3$ & 4 \\
\hline $\operatorname{rat}(\mathrm{m})$ & $0.81 \pm 0.11$ & $156.3 \pm 40.0$ & $0.87 \pm 0.17$ & $165.7 \pm 40.1$ & 3 & $10.2 \pm 3.7$ & $10.1 \pm 3.4$ & 14 \\
\hline rat (f) & $0.82 \pm 0.11$ & $141.1 \pm 80.0$ & $0.66 \pm 0.30$ & $140.7 \pm 79.8$ & 4 & $14.2 \pm 6.3$ & $11.5 \pm 4.7$ & 10 \\
\hline $\operatorname{pig}(\mathrm{m})$ & $0.57 \pm 0.05$ & $39.9 \pm 5.8$ & $0.55 \pm 0.16$ & $39.0 \pm 13.6$ & 3 & $3.4 \pm 1.0$ & $3.3 \pm 0.9$ & 8 \\
\hline pig (f) & $0.36 \pm 0.08$ & $11.3 \pm 4.2$ & $0.66 \pm 0.31$ & $16.7 \pm 7.0$ & 3 & $2.1 \pm 0.7$ & $2.0 \pm 0.6$ & 8 \\
\hline mouse (m) & $0.18 \pm 0.03$ & $2.7 \pm 1.9$ & n.c. & n.c. & 3 & $0.9 \pm 0.2$ & $0.9 \pm 0.2$ & 6 \\
\hline mouse (f) & $1.00 \pm 0.66$ & $23.1 \pm 25.2$ & n.c. & n.c. & 3 & $1.5 \pm 0.6$ & $1.5 \pm 0.5$ & 9 \\
\hline
\end{tabular}

Values are expressed as arithmetic means \pm SD from at least three independent preparations carried out in duplicate. $\mathrm{K}_{\mathrm{D}}$, equilibrium dissociation constant; $\mathrm{b}_{\max }$, maximum number of binding sites; $(\mathrm{m})$, male; (f), female; SB, specific binding; TB, total binding; n, number of independent experiments; n.c., not computable (poor correlation).

Values are calculated from ${ }^{\mathrm{a}}$ saturation binding experiments using nonlinear regression analysis, ${ }^{\mathrm{b}}$ saturation binding experiments using linear regression analysis (Scatchard-Plot), ${ }^{\mathrm{c}}$ control samples from competition binding experi-

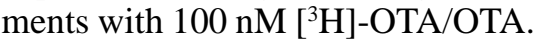

The competitive binding capacity of each test substance was determined using the same procedure as described for non-specific binding above except that increasing concentrations of potential competitors were added instead of excess OTA. All assays were carried out at least three times in duplicate and included both OTA and OTB as positive controls. The resulting data were plotted as percentage of control (specific-binding in the absence of competitor) versus the log of competitor concentrations.

Statistical analysis: Results from protein binding experiments were expressed as percentage vehicle control and analyzed with a one-tailed Dunnett's test. The effective concentrations causing $20 \%$ effect $\left(\mathrm{EC}_{20}\right)$ and $50 \%$ effect $\left(\mathrm{EC}_{50}\right)$ of each substance were calculated from concentration-response curves fitted by GraphPad Prism version 3.00 for Windows and Excel software (Microsoft Excel 2000). The data are presented as arithmetic means with their corresponding $95 \%$ confidence intervals, or, in the case of description of protein binding characteristics with their standard deviations (SD) (table 3 ).

\section{Results}

\section{Characterization of protein binding.}

Maximal specific binding of $\left[{ }^{3} \mathrm{H}\right]-\mathrm{OTA}$ to proteins of a renal cortex homogenate was achieved within 0.5 to 1 hour of incubation irrespective of the incubation temperature (fig. 1A and B). The relative binding-specificities of $\left[{ }^{3} \mathrm{H}\right]$-OTA were independent of the $\left[{ }^{3} \mathrm{H}\right]$-OTA concentration employed. In view of difficulties associated with maintaining a constant defined temperature of $4{ }^{\circ} \mathrm{C}$ or $37{ }^{\circ} \mathrm{C}$ over the 60 minute incubation period of the assay and the fact that the incubation at room temperature resulted in a comparable maximal specific binding of $\left[{ }^{3} \mathrm{H}\right]-$
OTA, all subsequent assays were carried out at room temperature.

Representative $\left[{ }^{3} \mathrm{H}\right]$-OTA binding curves (A) and Scatchard analysis (B) are shown in figure 2 for a male rat renal cortex homogenate incubated with varying concentrations of $\left[{ }^{3} \mathrm{H}\right]-\mathrm{OTA}$. The $\mathrm{K}_{\mathrm{D}}$ and $\mathrm{b}_{\max }$ values of all tested species were determined using Scatchard and non-
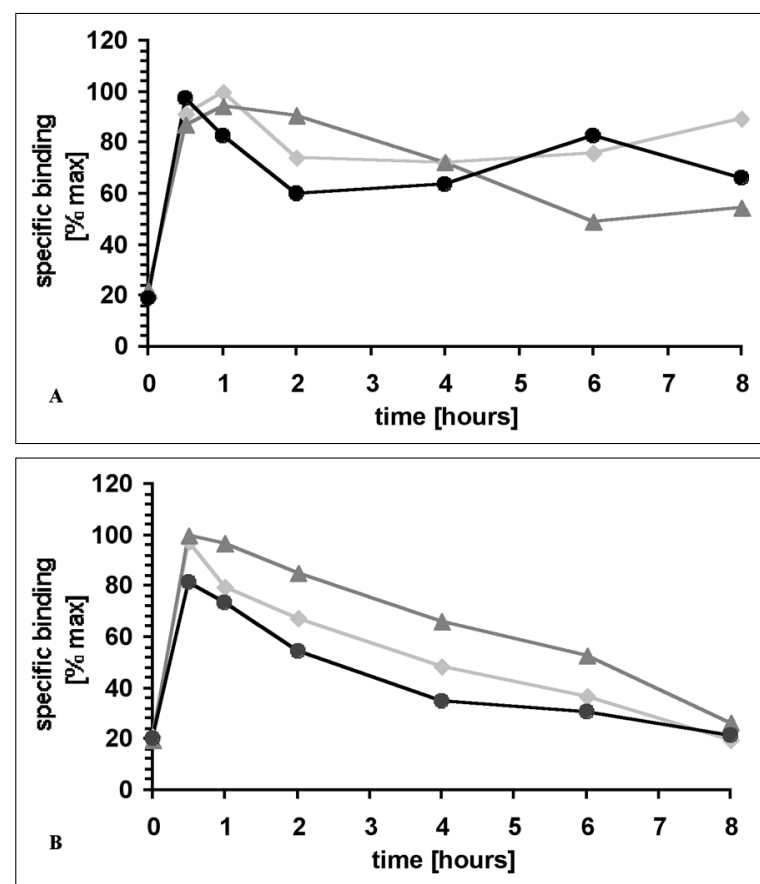

Fig. 1. Representative curves of time- and temperature-dependence of $[3 \mathrm{H}]-\mathrm{OTA}$ specific protein binding to male rat kidney homogenate. A: $1 \mathrm{nM}[3 \mathrm{H}]-\mathrm{OTA}, \mathrm{B}: 100 \mathrm{nM}[3 \mathrm{H}]-$ OTA; $4{ }^{\circ} \mathrm{C}(\triangle)$, room temperature $(\diamond), 37^{\circ} \mathrm{C}(\mathbf{O})$. 
linear regression analysis, respectively (table 3). Although Scatchard analysis is outdated for numerous mathematical reasons (distortion of the experimental error, violation of the assumption of linear regression) and therefore not ideal for use in this type of data analysis, it was used in this study in addition to non-linear regression analysis to allow for better comparison with the data in previously published studies. The data in table 3 suggested the presence of a homogeneous binding component having the characteristic of binding OTA in a specific and saturable manner. However, the $\mathrm{K}_{\mathrm{D}}$ and $\mathrm{b}_{\max }$ values displayed large SDs, presumably due to different levels of protein expression of the respective animals and human biopsy samples. In contrast, comparison of the values for specific binding, yielded a more reliable picture and obvious capacity ranking: human $>$ rat $>$ pig $\geq$ mouse, with human tissues having an approximately 20fold higher binding capacity for OTA than mouse renal cortex homogenates.

Concentration-response curves were generated for all species using OTA and OTB. As the curves for all species were similar, only figure 3 , which represents the behavior of human proteins, is shown. The data from other species are summarized in table 4. An OTA competition sensitivity ranking was deduced from the $\mathrm{EC}_{50}$ data

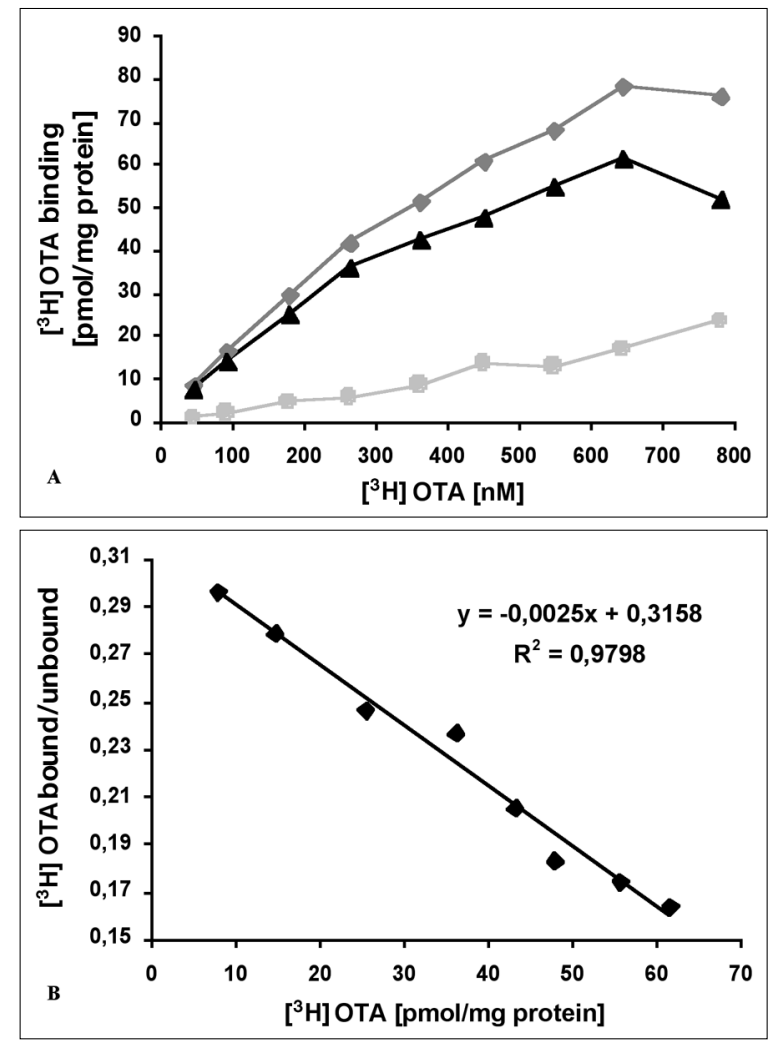

Fig. 2. A: Typical $[3 \mathrm{H}]-\mathrm{OTA}$ binding saturation curve with male rat kidney homogenate. Specific binding $(\boldsymbol{\Delta})$, total binding $(\diamond)$, unspecific binding $(\odot)$.

B: Scatchard plot derived from the data presented in A. Line fitted by linear regression. $[\mu \mathrm{M} \pm 95 \%$ confidence interval $]: \operatorname{rat}(\mathrm{m})[1.1 \pm 0.1]>$ $\operatorname{pig}(\mathrm{m})[2.1 \pm 0.5] \geq \operatorname{pig}(\mathrm{f})[2.5 \pm 0.4]>\operatorname{rat}(\mathrm{f})[3.0 \pm 0.3]$ $>\operatorname{human}(\mathrm{m})[4.7 \pm 0.1] \geq \operatorname{human}(\mathrm{f})[5.4 \pm 0.2]>$ $\operatorname{mouse}(\mathrm{m})[11.0 \pm 1.6] \geq \operatorname{mouse}(\mathrm{f})[13.0 \pm 1.5]$. Sex-differences were only apparent for protein binding in rat renal cortex homogenates (curves not shown), with males having an approximately 3-fold higher binding affinity for OTA than females.

\section{Competitive protein binding experiments.}

Several substances (table 2) were assayed as potential protein binding competitors of $\left[{ }^{3} \mathrm{H}\right]$-OTA. Sodium cholate, sodium chenodeoxycholate, digoxin, cholesterol, sodium taurocholate, $\alpha$-aldosterone, PAH, coumarin, testosterone, DL-phenylalanine, $\beta$-estradiol, sodium valproate, sodium dehydrocholate, GSH, sodium pyruvate, $\alpha$-ketoglutarate, cephaloridine, fumonisin $B_{1}$ and folic acid displayed no competition for $\left[{ }^{3} \mathrm{H}\right]-\mathrm{OTA}$ protein binding within the concentration ranges tested.

For those substances for which binding competition was demonstrated, different competition patterns were observed for each species (table 4). For comparison, $\mathrm{EC}_{20}$ values were calculated from the concentration-response curves.

As expected, a similar sensitivity ranking to OTA (see above) could be deduced for OTB using the $\mathrm{EC}_{50}$ data $[\mu \mathrm{M}$ ( $95 \%$ confidence interval]: $\operatorname{rat}(\mathrm{m})[12.0 \pm 1.0]>$ $\operatorname{human}(\mathrm{m})[27.0 \pm 2.0] \geq \operatorname{human}(\mathrm{f})[25.0 \pm 2.0]>\operatorname{rat}(f)$ $[35.0 \pm 2.0] \geq \operatorname{pig}(\mathrm{m})[38.0 \pm 11.0] \geq \operatorname{pig}(\mathrm{f})[42.0 \pm 8.0]>$ mouse(f) $[150.0 \pm 15.0] \geq \operatorname{mouse}(\mathrm{m})[160.0 \pm 30.0]$. Again, sex-differences were only apparent for protein binding in rat renal cortex homogenates (curves not

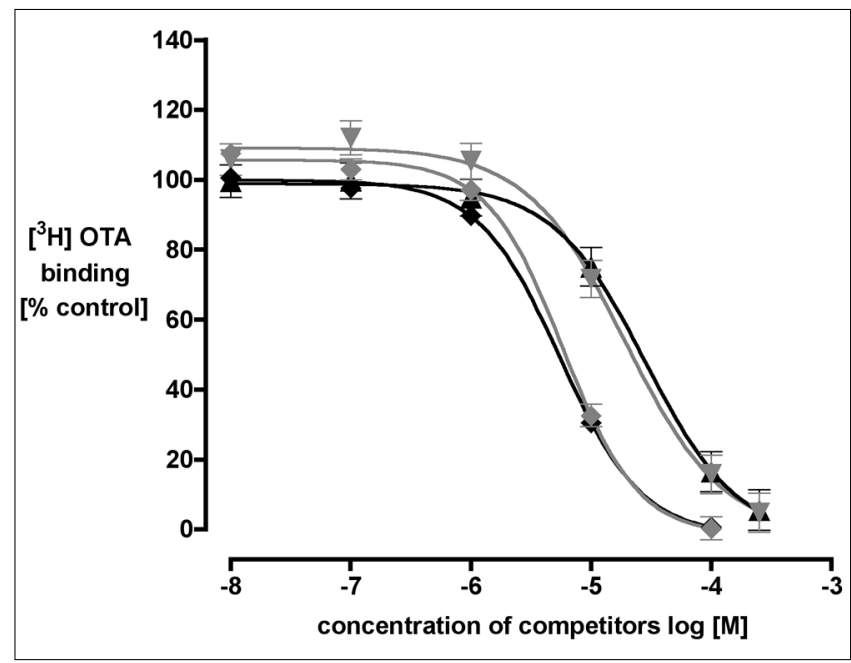

Fig. 3. Representative competitive binding of OTA and OTB to human kidney proteins. Values are expressed as arithmetic means with corresponding $95 \%$ confidence intervals from at least three independent preparations carried out in duplicate as described in the Methods section. ( $\diamond)$ OTA, female human; $(\nabla)$ OTB, female human; $(\diamond)$ OTA, male human; (A) OTB, male human. 
Table 4. Comparison of competition data $\left[\mathrm{EC}_{20}\right]$.

\begin{tabular}{|c|c|c|c|c|c|c|c|c|}
\hline \multicolumn{2}{|c|}{ substance human (m) } & \multirow{2}{*}{$\begin{array}{r}\text { human (f) } \\
\qquad 1.8 \pm 1.1\end{array}$} & \multirow{2}{*}{$\begin{array}{l}\text { rat }(\mathrm{m}) \\
0.18 \pm 0.02\end{array}$} & \multirow{2}{*}{$\begin{array}{l}\text { rat (f) } \\
\qquad 0.64 \pm 0.02\end{array}$} & \multirow{2}{*}{$\begin{array}{c}\text { mouse }(\mathrm{m}) \\
1.2 \pm 0.1\end{array}$} & \multirow{2}{*}{$\begin{array}{c}\text { mouse (f) } \\
1.7 \pm 0.1\end{array}$} & \multirow{2}{*}{$\begin{array}{l}\text { pig (m) } \\
0.48 \pm 0.13\end{array}$} & \multirow{2}{*}{$\begin{array}{l}\text { pig (f) } \\
0.24 \pm 0.01\end{array}$} \\
\hline & & & & & & & & \\
\hline 2 & & & $17+01$ & $9.9 \pm 0.3$ & $64 \pm 10$ & & & \\
\hline B & $0 \pm$ & 2 & 0.12 & 0.29 & & & 105 & 310 \\
\hline DHEAS & n. & n.e. & $370 \pm$ & $1,050 \pm 120$ & $110 \pm$ & $650 \pm 50$ & n.e. & n.e. \\
\hline IND & $22 \pm$ & $0.25 \pm 0.02$ & 6 & $3.4 \pm 0.1$ & n.e. & n.e. & $\mathrm{n}$. & $\mathrm{n}$ \\
\hline & & & & & 105 & & $35 \pm 3$ & $0.52=$ \\
\hline $101+8$ & $315 \pm$ & $460=$ & $310=$ & $39 \pm$ & & $120 \pm$ & n.e. & $240 \pm 10$ \\
\hline ET $A$ & $450 \pm$ & $340 \pm 50$ & $83 \pm$ & $290 \pm 10$ & $\mathrm{n}$. & n. & $1,750 \pm 250$ & n.e. \\
\hline PRO & $850 \pm 40$ & $1100 \pm 120$ & $130 \pm 10$ & $84 \pm 2$ & n.e. & n.e. & $205 \pm 15$ & $100 \pm 15$ \\
\hline PII & & & & & $\mathrm{n}$ & $280 \pm 10$ & 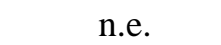 & $>1,000$ \\
\hline CPA & $720 \pm 10$ & $420 \pm 20$ & $320 \pm 30$ & $190 \pm 5$ & n.e. & n.e. & $1,200 \pm 50$ & $1,450 \pm 150$ \\
\hline
\end{tabular}

Values are expressed as arithmetic means of the effective concentrations $[\mu \mathrm{M}]$ causing $20 \%$ effect $\left(\mathrm{EC}_{20}\right)$ with corresponding $95 \%$ confidence intervals from at least three independent preparations carried out in duplicate. $(\mathrm{m})$, male; (f), female; n.e., no effects within the testing concentration range.

shown), with males having an approximately 3 -fold higher binding affinity for OTB than females. However, higher concentrations were necessary to achieve the same competition levels. For human proteins, this represented approximately a factor of 5 , approximately a factor of 10 for rat proteins and more than a factor of 15 for both mouse and porcine proteins.

BSP, a ligand for organic anion carriers expressed in the liver and kidney of the rat (KUSUHARA et al. 1999; TsudA et al. 1999), competed for [ $\left.{ }^{3} \mathrm{H}\right]$-OTA binding with a similar potency as OTA ( $\mathrm{nM}$ - low $\mu \mathrm{M}$ range) in rat and mouse. However, only weak competition was observed (high $\mu \mathrm{M}$ range) in the pig and human samples.

Indomethacin, a known inhibitor of the renal organic anion transporter of the rat (OAT1) (SEKINE et al. 1997), mouse (mOAT1) (KUZE et al. 1999) and human (hOAT1) (HOSOYAMADA et al. 1999), was a potent competitor of OTA (first effects in nM range) in the rat and human samples but not in the mouse or the pig. Kidney samples from female humans appeared nearly 10-fold more sensitive to OTA binding competition by indomethacin than the corresponding male samples (table 4), suggesting either differences in binding-protein expression levels or a completely different binding-protein expression pattern.

Furosemide, also an inhibitor of rat and human renal organic anion transporters (SEKINE, et al. 1997; Kusuhara et al. 1999; SAITO et al. 1996; Masuda et al. 1999, Hosoyamada et al. 1999), competed with $\left[{ }^{3} \mathrm{H}\right]-$ OTA only at higher concentrations in the rat and human and only very weakly in the mouse. However, furosemide was a potent competitor of $\left[{ }^{3} \mathrm{H}\right]$-OTA binding in pigs, with females displaying a flatter slope of the concentration-response curve than males. Indeed, females displayed first significant competition of OTA binding at a 60-fold lower furosemide concentration than the one necessary to obtain the same effect in males.
Piroxicam, a known inhibitor of rat organic anion transporters (Tsuda et al. 1999, KusUHARA et al. 1999), competed with human and rat $\left[{ }^{3} \mathrm{H}\right]$-OTA protein binding at relatively high concentrations (upper $\mu \mathrm{M}$ range). $\mathrm{Fe}-$ male mouse and female pig samples showed slight inhibition at millimolar concentrations, while male mouse and male pigs were completely refractive.

Only very weak competition was observed in rat and human samples with nalidixic acid, ethacrynic acid, probenecid and caprylic acid at relatively high concentrations ( $\mu \mathrm{M}$ to $\mathrm{mM}$ range). Similarly nalidixic acid provided a weak competion in female but not in male mouse samples. Millimolar concentrations of nalidixic acid, ethacrynic acid, probenecid and caprylic acid were necessary to produce binding inhibition in male and female pig samples, while ethacrynic acid, probenecid and caprylic acid had no competitive acitvity in either female or male mouse samples.

With the exception of DHEAS, none of the steroidal compounds had any competitive activity for OTA protein binding. DHEAS, at $\mu \mathrm{M}$ concentrations, inhibited $\left[{ }^{3} \mathrm{H}\right]-$ OTA protein binding however only in mouse and rat samples .

\section{Discussion}

The saturation binding curves and corresponding Scatchard analyses obtained with $\left[{ }^{3} \mathrm{H}\right]-\mathrm{OTA}$ and the kidney homogenates suggested the presence of a homogeneous binding component in all species tested. This (these) homogeneous binding component(s) characteristically bound OTA in a specific and saturable manner, while having a low affinity but high capacity for OTA binding. The latter was deduced from the fact that relatively high concentrations of OTA were necessary to 
achieve saturation. Elucidation of the nature and function of this (these) protein(s), with particular reference to the apparent species-differences, could promote a better understanding of the toxicity of OTA and hence provide a sound basis for risk extrapolation.

Due to the observed sex- and species-differerences in OTA toxicity both in vivo and in vitro (DIETRICH et al. 1995; DIETRICH et al. 2001; O'BRIEN et al. 2001), the first logical step was to investigate the effects of steroids on OTA binding to renal proteins. None of the substances tested in the current study (testosterone, estradiol and aldosterone) had any effect on protein binding. Preliminary studies in our laboratory using OTA as a potential competitor for $\left[{ }^{3} \mathrm{H}\right]$-estradiol binding to estrogen receptor(s) of various other species have also proved negative [data not shown]. Thus, the present data strongly suggest that the homogeneous binding component(s) does (do) not belong to the family of steroid receptors.

Another candidate function of this (these) binding component(s), which could account for the species-differences observed both in vivo and in vitro, is organic anion transport. It has been recently suggested that OTA may be transported into cells via such an organic anion transporter (OAT) mechanism (ENDOU 1998; RoCHRAMEL 1998; SAUVANT et al. 1998). These OATs are a family of proteins originally identified by their relative sensitivities to a variety of substances (competitors and inhibitors for binding to the transporter). A comparison of the binding and competition characteristics of such substances and a process of elimination can thus give indications to the identity of the binding-protein(s) in question. Therefore, the nature of the homogeneous OTA binding component(s) observed in this study, was investigated using an array of substances known to interact with OAT family members either as substrates or as transport competitors.

One such transporter is the rat renal organic anion transporter 1 (OAT1). This is a multispecific anion/dicarboxylate exchanger of the basolateral membrane of the proximal tubule (ENDOU 1998). TsudA and co-workers (1999) demonstrated OTA-transport into OAT1-expressing Xenopus laevis oocytes to be strongly inhibited by probenecid, piroxicam or $\mathrm{PAH}$, whereas aspartame has no effect. Other authors have shown that PAH-uptake via this transporter can be significantly inhibited by cephaloridine, nalidixic acid, furosemide, ethacrynic acid, indomethacin, probenecid, valproic acid or $\alpha$-ketoglutarate, whereas taurocholate has no effect (UWAI et al. 1998). Of the large number of substances tested with the rat protein homogenates in the study presented here, only nalidixic acid, furosemide, ethacrynic acid and indomethacin competed with $\left[{ }^{3} \mathrm{H}\right]-\mathrm{OTA}$ binding in a comparable concentration-response range to previously published observations, with inhibitor concentrations $>1,000$-fold higher than the employed $\left[{ }^{3} \mathrm{H}\right]$-OTA concentration necessary to show strong binding competition. All other substances competed either extremely weakly (probenecid and piroxicam) or not at all (PAH, cephaloridine, valproic acid, $\alpha$-ketoglutarate and taurocholate).

MDCK cells stably transfected with the rat renal multispecific organic anion transporter OAT-K2 have been shown to transport taurocholate. This transport could be inhibited almost completely by BSP, indomethacin, taurocholate, deoxycholate, and several other bile acids. Comparable concentrations of probenecid, PAH, furosemide and digoxin inhibited only to approximately 20-40\% control (MASUDA et al. 1999). The results presented here with the $\left[{ }^{3} \mathrm{H}\right]$-OTA protein-binding assay do not match the latter findings. Either very high concentrations ( $\geq 10,000$-fold) of these substances, compared to that of $\left[{ }^{3} \mathrm{H}\right]$-OTA, were necessary to show any binding competition, or no effect (taurocholate and other bile acids or digoxin) could be observed. This suggests the protein under investigation differs considerably from the previously characterized OAT-K2.

Previous authors have demonstrated that LLC-PK1 cells stably transfected with the rat renal apical multispecific organic anion transporter OAT-K1 transport methotrexate. This transport could be markedly inhibited by BSP and weakly inhibited by taurocholate, probenecid, $\mathrm{PAH}$, furosemide, valproate and indomethacin . The competitive $\left[{ }^{3} \mathrm{H}\right]$-OTA protein-binding assay employed in the study presented here, yielded a similar competition level only for furosemide and probenecid. In contrast, in the current study, BSP proved to have a far greater inhibitory effect than previously reported for this transporter (SAITO et al. 1996). Thus, comparison of the binding and competition data obtained suggests that the homogeneous OTA binding component found in the rat renal homogenates is not OAT1, OAT-K2 nor OAT-K1.

A potential candidate for the OTA binding-protein in human tissue is the human renal basolateral organic anion transporter (hOAT1). This transporter has been shown to have a substrate-specificity similar to that of the rat OAT1: PAH-uptake into hOAT1-expressing Xenopus laevis oocytes can be inhibited by $2 \mathrm{mM}$ furosemide, indomethacin, probenecid or $\alpha$-ketoglutarate (HosoyAmADA et al. 1999). In the current study, furosemide and indomethacin displayed moderate competition with $\left[{ }^{3} \mathrm{H}\right]-\mathrm{OTA}$ binding to human renal proteins, whereas excess concentrations of probenecid were necessary to produce even slight binding competition and $\alpha$ ketoglutarate did not have any effect at all. These discrepancies imply, that the homogenous OTA binding component found in renal tissue in this study, is not hOAT1.

Probenecid, $\alpha$-ketoglutarate and indomethacin have been previously reported to inhibit the mouse mOAT-mediated transport of PAH in mOAT-transfected COS-7 cells . In contrast, none of these substances had any inhibitory effect on $\left[{ }^{3} \mathrm{H}\right]-\mathrm{OTA}$ binding to mouse renal proteins, making it highly unlikely that the homogeneous OTA binding component in the mouse is identical to the already characterized mOAT. 
In summary, the $\left[{ }^{3} \mathrm{H}\right]-\mathrm{OTA}$ protein binding competition patterns observed in this study only partly match the previously described competition patterns for known OTA-transporting organic anion-transporter proteins. In conjunction with the high concentration of OTA necessary to achieve binding saturation, the latter findings suggest that none of the species-specific binding components belong to the presently-known organic anion transporters or steroid binding receptors or transporters.

The variations in OTA binding capacity and affinity observed in this study could also be explained by sexand species-specific differences in binding protein expression levels or patterns and could hence account for the observed species- and sex-specificities in OTA susceptibility. Indeed, we and other authors have recently proposed the existence of several cellular OTA-binding proteins of different molecular weights (STEMMER et al. 2002; SCHWERDT et al. 1999). Similar to the findings presented here, OTA-binding to these proteins could not be inhibited/competed by phenylalanine or aspartame (STEMMER et al. 2002). Preliminary assays in this laboratory have shown that OTA-binding proteins seem to be enriched in the cytosol but are also readily detectable in other cellular compartments (data not shown). Therefore, it is unlikely that a membrane transporter protein alone is responsible for the results obtained in this study.

Human renal proteins displayed a 2-20-fold higher $\left[{ }^{3} \mathrm{H}\right]-\mathrm{OTA}$ binding capacity than other species tested. This higher OTA binding capacity, in conjunction with the higher level of OTA uptake observed in human cells in vitro, when compared with other species, could at least in part, explain the 20- to 30-fold longer half-life of OTA in humans than that observed e.g. in rodents (STUDER-RoHR et al. 2000). Thus, OTA-binding protein(s) in humans appear to play a key role in the kinetics and hence possibly in the potential toxicity of OTA in humans. Consequently, the identification of this (these) protein(s) is essential for understanding the potential for toxicity of OTA in humans and thus for OTA-associated risk identification and management.

Acknowledgements: Ochratoxin A and B were kindly provided by Dr. M. E. Stack, U.S. FDA, Washington, D.C. Fumonosin B1 was a kind gift of Dr. P.C. Howard, NCTR, U.S. FDA, Washington, D.C. We would like to thank Prof. Dr. Hochberg, Prof. Dr. Thiel and their colleagues from the Department of Urology, Klinikum Konstanz for supplying us with human renal biopsy material.

\section{References}

Ballinger MB, Phillips TD, Kubena LF: Assessment of the distribution and elimination of ochratoxin a in the pregnant rat. J Food Safety 1986; 8: 11-24.

Bendele AM, Carlton WW, Krogh P, et al.: Ochratoxin A carcinogenesis in the $(\mathrm{C} 57 \mathrm{BL} / 6 \mathrm{~J} \times \mathrm{C} 3 \mathrm{H}) \mathrm{F} 1$ mouse. JNCL 1985; 75: 733-739.
BoORMAN GA: Toxicology and carcinogenesis studies of ochratoxin A in F344/N rats. NTP Technical Report NTP TR 358, 1989.

DieTrich DR, O’Brien E, STACK ME et al.: Species- and sex-specific renal cytotoxicity of ochratoxin A and B in vitro. Exp Toxic Pathol 2001; 53: 215-225.

DIETRICH DR, and RASONYI T: Preneoplastic lesions in kidney and carcinogenesis by non-genotoxic compounds. In Toxicology in transition (ed. G. H. Degen, J. P. SEILER and P. BENTLEY) 1995. Springer, Berlin.

Doster RC, Sinnhuber RO, Wales JH: Acute intraperitoneal toxicity of ochratoxin $\mathrm{A}$ and $\mathrm{B}$ in rainbow trout (Salmo gairdneri). Fd Cosmet Toxicol 1972; 10: 85-92.

ELLING F: Feeding experiments with ochratoxin A-contaminated Barely to bacon pigs. Acta Agric Scand 1983; 33: 153-159.

ENDOU H: Recent advances in molecular mechanisms of nephrotoxicity. Tox Lett 1998; 102-103: 29-33.

FuKUI Y, Hoshino K, KameYAma Y, et al.: Placental transfer of ochratoxin A and its cytotoxic effect on the mouse embryonic brain. Food Chem Toxicol 1987; 25: 17-24.

Galtier P, Alvinerie M, Charpenteau JL: The Pharmacokinetic profiles of ochratoxin $\mathrm{A}$ in pigs, rabbits and chickens. Food Cosmet Toxicol 1981; 19: 735-738.

Galtier P, Charpenteau JL, Alvinerie M, et al.: The pharmacokinetic profile of ochratoxin A in the rat after oral and intravenous administration. Drug Metab Dispos 1979; 7: 429-434.

Groves CE, Morales M, Wright SH: Peritubular transport of ochratoxin A in rabbit renal proximal tubules. J Pharmacol Exp Ther 1998; 284: 943-948.

Groves CE, NowaK G, Morales M.: Ochratoxin A secretion in primary cultures of rabbit renal proximal tubule cells. J Am Soc Nephrol 1999; 10: 13-20.

Hagelberg S, Hult K, Fuchs R: Toxicokinetics of ochratoxin A in several species and its plasma-binding properties. J Appl Toxicol 1989; 9: 91-96.

Hosoyamada M, SEKIne T, KANAI Y et al.: Molecular cloning and functional expression of a multispecific organic anion transporter from human kidney. Am J Physiol 1999; 276: F12-F128.

Kusuhara H, Sekine T, Utsunomiya-Tate N, et al.: Molecular cloning and characterization of a new multispecific organic anion transporter from rat brain. J Biol Chem 1999; 274: 13675-13680.

KUUZE K, GraVES P, LEAHY A, et al.: Heterologous expression and functional characterization of a mouse organic anion transporter in mammalian cells. J Biol Chem 1999; 274: 1519-1524.

Masuda S, Ibaramoto K, TAKeuchi A, et al.: Cloning and functional characterization of a new multispecific organic anion transporter, OAT-K2, in rat kidney. Mol Pharmacol 1999; 55: 743-752.

MASUdA S, SAITO H, INUI KI: Interactions of nonsteroidal anti-inflammatory drugs with rat renal organic anion transporter, OAT-K1. J Pharmacol Exp Ther 1997; 283: 1039-1042.

Mortensen HP, Hald B, Madsen A: Feeding experiments with ochratoxin A contaminated barley for bacon pigs: 5 . Ochratoxin A in pig blood. Acta Agric Scand 1983; 33: 235-239.

Nimrod AC, Benson WH: Xenobiotic interaction with and alteration of channel catfish estrogen receptor. Toxicol Appl Pharmacol 1997; 147: 381-390. 
O'Brien E, Heissner AH, Dietrich DR: Species-, sex- and cell type specific effects of ochratoxin A and B. Toxicol Sci 2001; 63: 256-264.

PeCKHAM JC, Doupnik B, Jones OH: Acute toxicity of ochratoxin A and B in chicks. Appl Microbiol 1971; 21: 492-494.

RAsOnYI T, Schlatter J, DiETRICH DR: The role of alpha2u-globulin in OTA induced renal toxicity and tumors in F344 rats. Tox Lett 1999; 104: 83 - 92.

RoCH-RAMEL F: Renal transport of organic anions. Curr Opin Nephrol Hypertens 1998; 7: 517-524.

SAITO H, MAsuda S, INUI KI: Cloning and functional characterization of a novel rat organic anion transporter mediating basolateral uptake of methotrexate in the kidney. J Biol Chem 1996; 271: 20719-20725.

Sauvant C, Silbernagel S, GeKLe M: Exposure to ochratoxin A impairs organic anion transport in proximaltubule-derived opossum kidney cells. J Pharmacol Exp Ther 1998; 287: 13-20.

SCATCHARD G: The attractions of proteins for small molecules and ions. Ann NY Acad Sci 1949; 51: 660-672.

SChWERdt G, Freudinger R, Silbernagel S, et al.: Ochratoxin A-binding proteins in rat organs and plasma and in different cell lines of the kidney. Toxicol 1999; 135: $1-10$.

SEKIne T, Cha SH, Tsudam, et al.: Identification of multispecific organic anion transporter

2 expressed predominantly in the liver. FEBS Lett 1998; 429: $179-182$.

Sekine T, Watanabe N, Hosoyamada M, et al.: Expression cloning and characterization of a novel multispecific organic anion transporter. J Biol Chem 1997; 272: 18526-18529.

SPEIJERS GJA, VAN EGMOND HP: Worldwide ochratoxin A levels in food and feeds. In: Human ochratoxicosis and its pathologies, 1993, vol. 231. Colloques INSERM, pp. 85-100. John Libbey Eurotext Ltd., Montrouge, France.

Stemmer K, Heussner AH, Stack E et al.: Comparison of ochratoxin binding to human, porcine and rat renal proteins in vitro. Toxicol Sci 2002; 66(1-S): 400.

StUder-Rohr I, Dietrich DR, Schlatter J, et al.: The occurrence of ochratoxin A in coffee. Food Chem Toxicol 1995; 33: 341-355.

StUDER-RoHR J, SCHLATTER J, DIETRICH DR: Intraindividual variation in plasma levels and kinetic parameters of ochratoxin A in humans. Arch Toxicol 2000; 74: 499-520.

SweEt DH, WolfF NA, Pritchard JB: Expression cloning and characterization of ROAT1. J Biol Chem 1997; 272: 30088-30095.

TATU CA, Orem WH, Finkelman RB, et al.: The etiology of balkan endemic nephropathy: still more questions than answers. Environ Health Perspect 1998; 106: $689-700$

TsudA M, SEKINE T, TAKEDA M, et al.: Transport of ochratoxin A by renal multispecific organic anion transporter 1. J Pharmacol Exp Ther 1999; 289: 1301-1305.

UWAI Y, OKUDA M, TAKAMI K, et al.: Functional characterization of the rat multispecific organic anion transporter OAT1 mediating basolateral uptake of anionic drugs in the kidney. FEBS Lett 1998; 438: 321-324.

WelboRN JR, GROVES CE, WRIGHT SH: Peritubular trasnport of ochratoxin A by single rabbit renal proximal tubules. J Am Soc Nephrol 1998; 9: 1973-1982.

WolfF J, Bresch H, Cholmakow-Bodechtel C, et al.: Belastung des Verbrauchers und der Lebensmittel mit Ochratoxin A, 2000, pp. 243. Forschungsverbund Produkt- und Ernährungsforschung des Bundesministeriums für Ernährung, Landwirtschaft und Forsten, Berlin. 